\title{
Replication and mitigation of effects of confounding variables in environmental impact assessment: effect of marinas on rocky-shore assemblages
}

\author{
Lisandro Benedetti-Cecchi ${ }^{1,2, *}$, Giacomo Chato Osio ${ }^{1}$ \\ ${ }^{1}$ Dipartimento di Biologia, Via A. Volta 6, 56126 Pisa, Italy \\ ${ }^{2}$ Present address: University of New Hampshire, Durham, New Hampshire 03824, USA
}

\begin{abstract}
Design- and model-based approaches provide 2 distinct frameworks in which to analyse environmental impacts. While both approaches have been criticized to some extent, the possibility of modeling environmental variability with covariates in the analysis of structured sampling designs seems to have eluded the attention of environmental ecologists. We applied a beyond-BACI (before, after, control, impact) sampling design to a post-impact study on the effects of marinas on assemblages of algae and invertebrates on rocky seashores at 2 locations in the NW Mediterranean. The 2 locations were on the opposite (northern and southern) sides of a promontory, about $30 \mathrm{~km}$ apart. A shore next to the marina and 3 reference shores were sampled at each location to obtain independent estimates of differences between disturbed and undisturbed conditions. An additional set of 3 shores were sampled at a location on the western coast to test whether structured spatial patterns around the promontory might confound the analysis of impact. Midshore and lowshore habitats were sampled on all shores. Multivariate and univariate analyses revealed differences between disturbed and reference assemblages mostly at one location in the midshore habitat. Analyses conducted on the lowshore data indicated that assemblages of marinas followed different temporal trajectories than reference shores consistently at the 2 locations. Spatial variability around the promontory was large, as indicated by significant linear and quadratic contrasts among all locations. When impacts were examined using either the geographic position of shores or their rank position around the promontory as a covariate, results did not differ from those of the original analyses. The present study highlights possible ways to overcome the dichotomy between design- and model-based approaches, namely that studies of impact can and should be examined at replicated locations whenever possible and that covariables can be included in the analysis of structured sampling designs to increase precision and accuracy in assessment of environmental impacts.
\end{abstract}

KEY WORDS: Beyond-BACI designs · Confounding variables · Environmental impacts · Pollution · Rocky shores $\cdot$ Spatial variability $\cdot$ Temporal variability

\section{INTRODUCTION}

Assessment of environmental impacts is complicated by the fact that multiple processes contribute to generate variability in the distribution and abundance of plants and animals. Teasing apart anthropogenic influences from other causes of variation is a daunting task when the size of natural populations fluctuates largely in space and time, which is commonly the case. In the last 30 yr considerable progress has been made in applying the principles of experimental design to the analysis of environmental impacts and in the development of appropriate statistical techniques (Green 1979, Bernstein \& Zalinski 1983, Eberhardt \& Thomas 1991, Schmitt \& Osenberg 1996). The need for multiple control sites and the development of specific univariate 
and multivariate methods of analysis are examples of these achievements (Underwood 1992, Clarke 1993, Anderson 2001, Terlizzi et al. 2005).

Although research continues on how to make environmental sampling programs more efficient and powerful (Benedetti-Cecchi 2001a, Hewitt et al. 2001, Underwood \& Chapman 2003), there is no general consensus about the most appropriate strategy to increase precision and accuracy in assessment of environmental impacts. A major difficulty is that of estimating the parameter of interest (e.g. mean population abundance) that would be expected at the disturbed site in the absence of human intervention. A common recommendation is that of sampling multiple control sites to estimate the expected value of the parameter and to measure natural variability among sites in the absence of disturbance (Chapman et al. 1995, Glasby 1997, Roberts et al. 1998, Bishop et al. 2002, Guidetti et al. 2002, 2003, Terlizzi et al. 2005). The estimate of the expected value of the parameter is the reference measure against which an observed value is compared. For this purpose, controls must be selected randomly and independently from a population of sites to represent the same type of habitat as that in the disturbed site. This requires that controls are established in the same geographic area as the disturbed site, but far enough a way as to be outside the range of influence of the particular source of anthropogenic disturbance being examined. This approach relies on classical theory of experimental design and provides the basis of the beyond-BACI type of designs (Underwood 1991, 1992). Although the inferential strength of these designs is largest when data from both the periods before and after the intervention are available, they can be applied also to post-impact studies (Underwood 1992).

Recently, some of the principles underpinning this procedure have been questioned (Stewart-Oaten \& Bence 2001). In particular, because studies usually deal with a single disturbed site and not with a population of such units and because disturbance is not allocated randomly to a site, a design-based approach to the assessment of environmental impacts may lead to invalid inferences. As an alternative, model-based studies in which control sites are treated as covariates rather than as experimental units have been proposed. In this framework, control sites are deliberately chosen to be correlated with the disturbed site in order to remove or reduce the effects of confounding variables. Thus, values of response variables obtained at control sites can be used as covariates to increase accuracy and precision in estimating the effects of human intervention. Environmental variables like wave exposure and temperature, and spatial variables like geographical coordinates can be used as covariables. The use of spatial variables as covariates is common in studies aimed at describing spatial variability in assemblages (e.g. Dutilleul 1993, Legendre \& Legendre 1998), but it is still overlooked in studies of impact.

In this study, we compared assemblages of algae and invertebrates of rocky shores next to marinas to those of reference shores far from this source of disturbance to test the hypothesis that these assemblages differ in composition and abundance of taxa. We define disturbance as any kind of human intervention that may or may not cause an impact (Connell \& Glasby 1999, Bulleri \& Chapman 2004), with an impact defined as a difference between disturbed and reference shores in structure of assemblages or in any other relevant ecological variable caused by disturbance. The study was undertaken along the shores of a promontory on the west coast of Italy (NW Mediterranean), over a period of $3 \mathrm{yr}$. We replicated the study at 2 localities with independent marinas and reference shores in each case. Limited availability of hard substrata made it impossible to intersperse disturbed and reference shores properly at 1 locality, raising potential problems of spatial confounding (e.g. Glasby \& Underwood 1998). To test whether there were structured spatial patterns along the promontory that might confound the analysis of impact (e.g. because of gradients in wave exposure, see Fig. 1), we sampled an additional set of shores on the W/SW (seaward) side of the promontory for comparison with the reference shores at the 2 localities with marinas. This design-based approach was integrated with a model-based one in which the analysis of impacts was repeated after removing possible spatial effects from the data using the position of shores around the promontory as a covariable. This investigation illustrates 2 important issues that transcend the dichotomy between design- and modelbased strategies, namely that studies of impact can and should be replicated at multiple locations whenever possible and that covariables can be included in the analysis of structured sampling designs to reduce the influence of potentially confounding variables in studies of impact.

\section{MATERIALS AND METHODS}

Study system. The study was carried out along the shores of Monte Argentario, a promontory of about $30 \mathrm{~km}$ of coastline in western Italy. The 2 marinas were Porto S. Stefano (PSS, up to 400 boats) and Porto Ercole (PE, up to 800 boats), located on the opposite sides of the promontory (Fig. 1). Both marinas have been established for at least $40 \mathrm{yr}$. The biota of these shores was similar to that described for other localities in the same geographical area (Benedetti-Cecchi 2001b, Benedetti- 


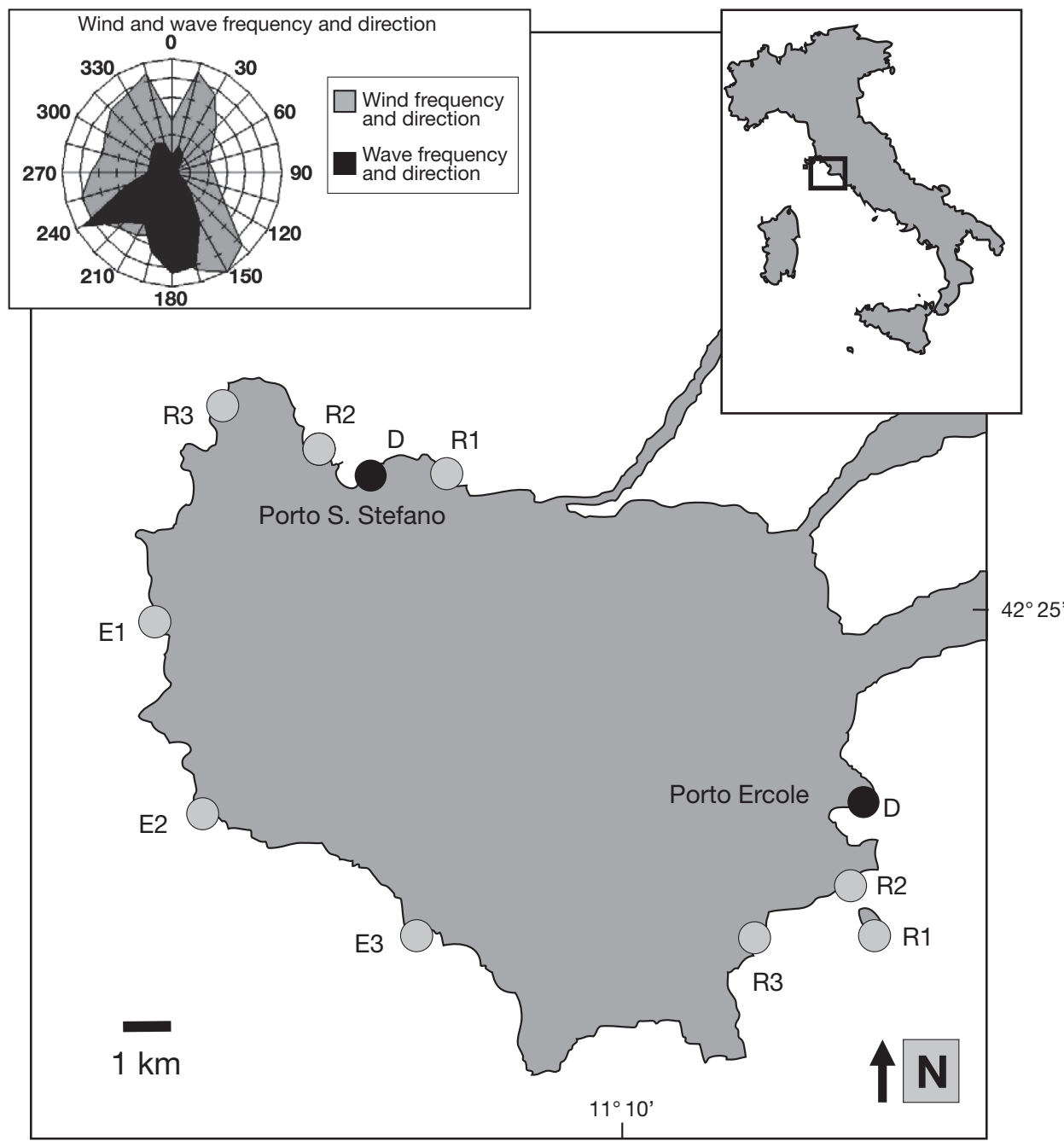

Fig. 1. Study area, showing disturbed (D), reference (R) and W/SW, exposed (E) rocky shores in western Italy. Frequencies and directions of waves and winds are from the Mediterranean Wind Wave Atlas (Cavaleri 2005), covering the period 1992 to 2002. Data show that the strongest waves in the area originated from the 160 to $240^{\circ}$ sector and that shores E1 to E3 and R3 of Porto Ercole were the most exposed to wave action, and also that wave action was a potential confounding variable in assessing impacts at Porto Ercole, where the disturbed shore was spatially segregated from reference shores

Cecchi et al. 2003). The midshore habitat (between 0.1 and $0.3 \mathrm{~m}$ above mean low water level) was occupied by filamentous algae such as Polysiphonia sertularioides (Grateloup) and Chaetomorpha aerea (Dillwyn) Kützing, encrusting corallines, the encrusting brown alga Ralfsia verrucosa (Aresho ug) J. Agardh, the fleshy alga Rissoella verruculosa (Bertolini) J. Agardh and cyanobacteria (Rivularia spp.). Invertebrates included the barnacles Chthamalus montagui Southward and C. stellatus (Poli), the limpets Patella rustica L. and the topshell Osilinus turbinatus (Von Born). The lowshore habitat (from -0.1 to $+0.1 \mathrm{~m}$ with respect to mean low water level) was dominated by turf-forming algae such as Corallina elongata Ellis et Solander and Haliptilon virgatum (Zanardini) Garbary and Johansen, coarsely branched algae like Laurencia spp., Chondria spp. and
Gastroclonium clavatum (Roth) Ardissone and several species of filamentous algae. Canopy algae such as Cystoseira amentacea Bory var. stricta Montagne and sessile invertebrates (mainly sponges, hydrozoans, bryozoans and actinians) were sparse at the study site. The most abundant grazers in the lowshore habitat were the limpets Patella ulyssiponensis Gmelin, 1971 and $P$. caerulea Linné.

Sampling design and collection of data. Both localities had a rocky shore adjacent to the entrance of the marina, which was designated the disturbed shore. Both shores faced the open sea and were unprotected by breakwaters. Three reference shores were chosen among those available at distances of 1 to $5 \mathrm{~km}$ from each marina, using a random selection procedure. Initial criteria for selection included similarities between 
disturbed and reference shores in terms of geographical orientation, type of substratum and aspect (i.e. continuous shores populated by assemblages of algae and invertebrates). Furthermore, reference shores should occur on both sides of the disturbed ones to avoid spatial segregation. This condition was relaxed at PE because we could not find a suitable rocky habitat north of the marina for this locality. At PSS, in contrast, only 1 shore was available east of the marina and this shore was chosen deliberately. All other shores were selected randomly among those that satisfied the requirements indicated above.

Three additional shores were sampled on the W/SW and most exposed side of the promontory and used together with the reference shores to test whether there was significantly larger variation in assemblages among localities with different geographical positioning, over and above differences among shores in each locality. This comparison was used as a measure of the degree to which spatial segregation between reference and disturbed shores might have confounded the analysis of impact (indeed, this problem was only present at PE). In the event that variability among shores was larger than variability among locations, which included the contrast between exposed and sheltered conditions (see Fig. 1), position around the promontory was relatively unimportant and spatial segregation was considered a minor problem. Otherwise, effects of position should be taken into account (see 'Analysis of data').

Shores were 30 to $50 \mathrm{~m}$ in spatial extent and were sampled at 2 heights corresponding to the midshore and lowshore habitats. Sampling was usually done every 3 to 5 mo between May 1998 and March 2001, on a total of 10 sampling dates. The last sampling date, March 2001, was more than 12 mo later than the previous one (indicated as T1 to T10 in Figs. 3 to 5, where T1 = May 1998, T2 = June 1998, T3 = September 1998, $\mathrm{T} 4=$ December 1998, $\mathrm{T} 5=$ March 1999, $\mathrm{T} 6=$ June 1999, T7 $=$ September 1999, T8 = January 2000, T9 = April 2000, T10 $=$ March 2001). On each date, 8 replicate quadrats of $20 \times 20 \mathrm{~cm}$ each were located randomly on each habitat of each shore and sampled visually. A plastic frame with 25 squares of $4 \times 4 \mathrm{~cm}$ each was used to delimit the sampling area. Percent cover values of sessile organisms (algae and invertebrates) was determined by assigning to each taxon a score ranging from 0 to 4 and adding up the 25 estimates (Dethier et al. 1993). Final values were expressed as percentages. Densities of mobile gastropods were expressed as number of individuals per quadrat. Taxa were examined at the most detailed level of taxonomic resolution that was possible to achieve in the field. Organisms that could not be identified at the levels of species or genus or that were too sparse to be ana- lysed individually, were lumped into morphological groups (Littler \& Littler 1980, Steneck \& Watling 1982). These included encrusting and articulated coralline algae, filamentous algae and coarsely branched algae. Two species of limpets, Patella ulyssiponensis and $P$. caerulea, were also considered as a single group because they could not be distinguished in the field. Similarly, the barnacles Chthamalus montagui and C. stellatus were combined.

Analysis of data. Data were analysed with multivariate and univariate techniques to test the hypothesis that the structure of assemblages and the abundance of single taxa differed between disturbed and reference shores and to assess the extent to which position around the promontory might have affected these comparisons. Permutational multivariate analysis of variance (PERMANOVA, Anderson 2001) based on Bray-Curtis untransformed dissimilarities was used to analyse the multivariate assemblage data. The original design consisted of three factors: location (random with 2 levels, PSS and PE), shore (4 levels, random, nested in location) and time (10 levels, random and crossed with both location and shore). The total multivariate variability was partitioned in a way analogous to the procedure described by Glasby (1997) for the univariate case. Thus, the analysis included the contrast between disturbed and reference shores and the 2and 3-way interactions between this contrast and factors location and time. These tests examined the consistency (or the variation) of any difference between disturbed and reference shores in space and time (see also Terlizzi et al. 2005 for another example of multivariate contrasts between disturbed and reference conditions). Each term in the analysis was tested individually over the appropriate denominator (with 999 random permutations of the relevant units) using the computer program DISTLM.exe (Anderson 2004). Because there was only 1 disturbed shore at each location, this was an asymmetrical design (Underwood 1992, 1997).

The SIMPER procedure (Clarke 1993) was used to identify the percentage contribution $\left(\delta_{i} \%\right)$ of each taxon (or species) to the Bray-Curtis dissimilarity between the averages of disturbed and reference shores $\left(\delta_{i}\right)$. Species (or taxa) were considered important if their contribution to percentage dissimilarity was $\geq 3 \%$. The ratio $\delta_{i}: \operatorname{SD}\left(\delta_{i}\right)$ was used to indicate the consistency with which a given taxon contributed to the average dissimilarity in all pairwise comparisons of samples between disturbed and reference shores. Values $\geq 1$ indicated a high degree of consistency.

PERMANOVA was used to compare assemblages among the 3 geographical positions around the promontory: PSS, PE and the W/SW, more exposed, rocky shores (E). This comparison excluded the disturbed 
shores of PSS and PE and the design consisted of 3 factors: location (fixed with three levels: PSS, E and PE), shore (3 levels, random, nested in location) and time (10 levels, random, crossed with both location and Site). The analysis examined linear and quadratic contrasts among localities. Linear contrasts (PS vs. PE) tested the hypothesis that assemblages differed in response to spatial gradients along the promontory. Quadratic contrasts (E vs. others) tested the hypothesis that assemblages located on the W/SW shores of the promontory differed from those of the other shores. Support for any of these hypotheses would indicate the existence of spatial processes associated with the geographical orientation of a shore that might have confounded the analysis of impact. In such case, the analysis of impact was repeated using the geographical coordinates of each shore as covariables. Indeed, only latitude was used in this and subsequent analyses because latitude and longitude were highly correlated ( $\mathrm{r}=-0.95, \mathrm{p}<0.0001, \mathrm{n}=8)$. As an alternative method to model spatial variation, we repeated the analyses using the rank order of the position of shores around the promontory (starting from the disturbed shore at $\mathrm{PE}$ and running counter-clockwise) as a covariable. The results of the 2 analyses were, however, qualitatively similar and only those with latitude as the covariate are reported here.

When there were too few possible permutations to obtain a test with reasonable power in the multivariate analyses, a p-value was calculated using 999 Monte Carlo draws from the appropriate asymptotic permutation distribution (Anderson \& Robinson 2003).

Non-metric multidimensional scaling (nMDS) was used to illustrate significant multivariate patterns. This required plots of the centroids of the 8 cells corresponding to the disturbed and reference shores of each locality for the midshore habitat and the 20 cells corresponding to the time $\times$ disturbed vs. reference shores interaction for the lowshore habitat. Centroids were calculated from principal coordinates obtained from the full Bray-Curtis dissimilarity matrix among the 640 observations in each habitat (McArdle \& Anderson 2001). Euclidean distances were then obtained between each pair of centroids and used as the input matrix for the nMDS. Centroids and distances among them in BrayCurtis space were obtained using the computer program PCO.exe (Anderson 2003); nMDS plots were generated with PRIMER (Clarke \& Gorley 2001).

Analysis of variance (ANOVA) was used to examine patterns of variation in abundance of single taxa in relation to marinas and geographical position. The same models of analysis as those described for the multivariate case were used. When appropriate, SNK tests were employed for a posteriori multiple comparisons of means. Cochran's $C$-test was used to examine the as- sumptions of homogeneity of variances. Analyses were done on transformed data when variances were not homogenous and when transformations removed the heterogeneity. When variances could not be stabilized with transformations, analyses were done on untransformed data at the more conservative significance level of $\alpha=0.01$. Analysis of variance was done using GMAV 5 software (University of Sydney, Australia).

Effects of geographical position (including linear and quadratic contrasts) were examined as described for the multivariate case. When an effect of position was found, impacts were examined using analysis of covariance (ANCOVA) with latitude or the rank position of shores around the promontory as the covariate. These analyses were undertaken only if both assumptions of ANOVA and regression were met (Huitema 1980, Underwood 1997). Additional assumptions included (1) the dependent variable was linearly and significantly related to the covariable, (2) within group regressions were homogeneous. Although violation of these assumptions would not prevent the fit of an ANCOVA model (which would include an interaction between the categorical and the continuous predictors, see below), comparing treatment means (e.g. reference vs. disturbed shores after adjusting for differences in geographic position) requires homogeneous slopes. We further assumed that the covariate was measured without error and that it was independent of treatment effects. Linear regression was used to test whether there were significant relationships between dependent variables and the covariable. Plots of residuals vs. predicted values were examined to check whether there were strong departures from the assumption of normality. Homogeneity of slopes was examined by testing treatment $\times$ covariate interactions for the terms of interest. For example, if the analysis revealed a significant time $\times$ disturbance interaction after correcting for effects of geographical position, then a test of the time $\times$ disturbance $\times$ latitude interaction was done before attempting to interpret the analysis. Choice of the denominator mean square for a given test was based on the same criteria used in ANOVAs. Thus, the mean square of the time $\times$ location $\times$ disturbance $\times$ latitude interaction would be used as the denominator for the above test. Tests of homogeneity of slopes can, however, be tricky in complex designs (Quinn \& Keough 2002). In the present study, a single measure of the covariate was associated with each shore, so that any test that included the term 'shore' could not be crossed with 'latitude'. As a consequence, a test of homogeneity of slopes that used the time $\times$ location $\times$ disturbance $\times$ latitude interaction, which would ideally be tested over the time $\times$ reference shore (location) $\times$ latitude term, was done on the time $\times$ reference shore (location) instead. Mean squares for ANCOVAs were obtained with R2.01 (R Development Core Team 2003). 


\section{RESULTS}

\section{Multivariate analyses}

A total of 24 taxa were identified in the midshore habitat. Assemblages in this habitat differed significantly between disturbed and reference shores at PSS, but not at PE (Table 1). Variability was large at PE, where 1 of the reference shores supported very similar assemblages to those on the disturbed shore (Fig. 2a).

SIMPER analysis identified 6 taxa as important (i.e. contributing to $\geq 3 \%$ of percentage dissimilarity) in discriminating between disturbed and reference shores at PSS (Table 2). Rivularia spp., Chthamalus spp. and Ralfsia verrucosa were more abundant on the disturbed shore, whilst encrusting algae, filamentous algae and Patella rustica were more abundant on reference shores. The contribution of cyanobacteria and barnacles to percentage dissimilarities was highly consistent among pairwise comparisons of samples between the 2 groups (Table 2).

The analysis of spatial effects revealed a significant interaction between time and the linear contrast for location (Table 3). This indicated temporally variable differences in assemblages at large spatial scales along the promontory. These effects were unlikely to confound the analysis of impact at PSS, where reference and disturbed shores were properly interspersed. In addition, repeating the analysis of impact with geographic coordinates as covariables generated very similar results to those obtained from the original analysis, with a significant difference between dis- a) Midshore habitat

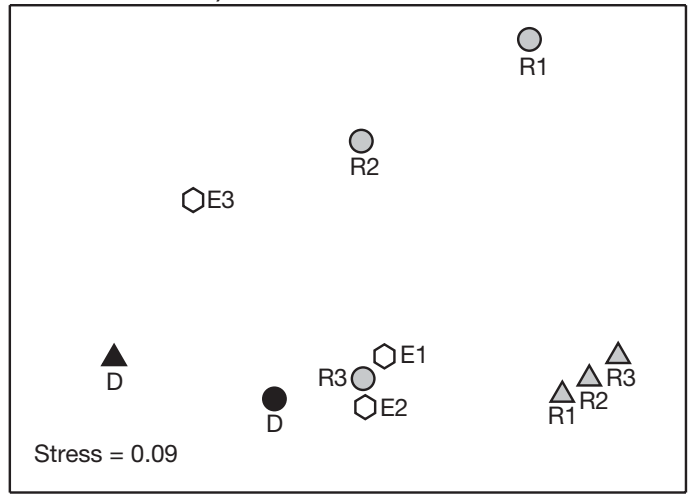

b) Lowshore habitat

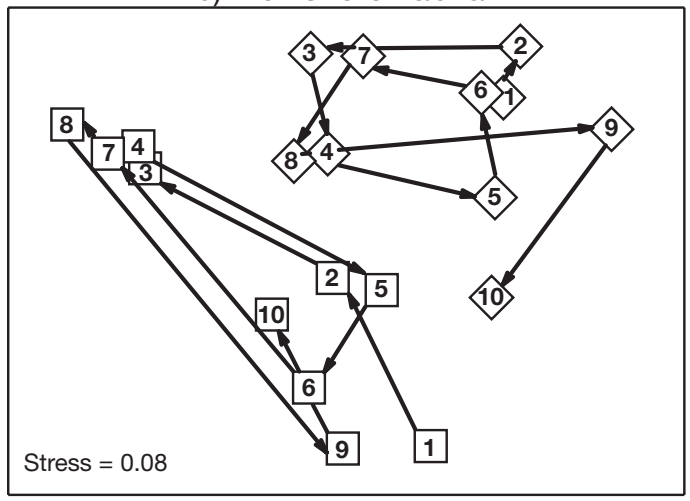

Fig. 2. nMDS plots. (a) Centroids of disturbed $(\boldsymbol{O}, \mathbf{\Delta})$ and reference $(O, \Delta)$ shores at Porto Ercole $(\boldsymbol{O}, \bigcirc)$ and Porto S. Stefano $(\boldsymbol{\Lambda}, \triangle)$ and of exposed shores $(\triangle)$ for midshore habitat. (b) Temporal trajectories of centroids for disturbed $(\diamond)$ and reference $(\square)$ conditions over the 10 sampling dates for the lowshore habitat

Table 1. Permutational multivariate analysis of variance (PERMANOVA) on data from midshore and lowshore habitats (Ref. $=$ reference shores). Main effects of Location and Time were not tested because they were irrelevant to assessment of impact and their significance did not affect the way more relevant tests were constructed $(\mathrm{nt}=$ no test). PSS $=$ Porto S. Stefano; PE $=$ Porto Ercole $; \mathrm{p}(\mathrm{MC})=\mathrm{p}$-value calculated by Monte Carlo method

\begin{tabular}{|c|c|c|c|c|c|c|c|c|c|}
\hline \multirow{2}{*}{ Source of variation } & \multirow[t]{2}{*}{$\mathrm{df}$} & \multicolumn{4}{|c|}{ Midshore habitat } & \multicolumn{3}{|c|}{ — Lowshore habitat _- } & \multirow{2}{*}{$\begin{array}{l}\text { Permutable units and } \\
\text { denominator for } F\end{array}$} \\
\hline & & MS & $F$ & $\mathrm{p}$ & $\mathrm{p}(\mathrm{MC})$ & MS & $F$ & $\mathrm{p}$ & \\
\hline Location (L) & 1 & 43398 & & & & 5792 & & & \\
\hline Disturbed (D) vs. Ref. (R) & 1 & 99126 & 1.7 & 1.0 & 0.13 & 91112 & nt & & $4 \mathrm{~L} \times \mathrm{D}$ cells \\
\hline $\mathrm{L} \times \mathrm{D}$ & 1 & 56713 & 2.5 & 0.07 & 0.03 & 6894 & 0.2 & 1.0 & 8 Shore $(\mathrm{L})$ cells $^{\mathrm{a}}$ \\
\hline $\mathrm{R}(\mathrm{L})$ & 4 & 22454 & 7.3 & 0.001 & & 35544 & 9.2 & 0.001 & $60 \mathrm{~T} \times \mathrm{R}(\mathrm{L})$ cells \\
\hline Time (T) & 9 & 9669 & & & & 20545 & & & \\
\hline $\mathrm{T} \times \mathrm{L}$ & 9 & 5366 & 1.7 & 0.003 & & 3492 & 1.2 & 0.3 & $80 \mathrm{~T} \times$ Shore $(\mathrm{L})$ cells \\
\hline $\mathrm{T} \times \mathrm{D}$ & 9 & 4050 & 1.2 & 0.25 & & 3283 & 2.6 & 0.005 & $40 \mathrm{~T} \times \mathrm{L} \times \mathrm{D}$ cells \\
\hline $\mathrm{T} \times \mathrm{L} \times \mathrm{D}$ & 9 & 3322 & 1.1 & 0.35 & & 1270 & 0.3 & 1.0 & $80 \mathrm{~T} \times$ Shore $(\mathrm{L})$ cells $^{\mathrm{a}}$ \\
\hline $\mathrm{T} \times \mathrm{R}(\mathrm{L})$ & 36 & 3081 & 2.5 & 0.001 & & 3859 & 3.7 & 0.001 & 640 raw units \\
\hline Residual & 560 & 1145 & & & & 943 & & & \\
\hline \multicolumn{10}{|l|}{$\begin{array}{l}\text { Comparisons within } \\
\mathrm{L} \times \mathrm{D} \text { interaction }\end{array}$} \\
\hline PSS & 1 & 126765 & 5.6 & 0.004 & & & & & 8 Shore $(\mathrm{L})$ cells $^{\mathrm{a}}$ \\
\hline $\mathrm{PE}$ & 1 & 29074 & 1.3 & 0.3 & & & & & 8 Shore(L) cells ${ }^{a}$ \\
\hline
\end{tabular}


turbed and reference shores only at PSS (mean square of disturbed vs. reference shores $=120599$, Mean Square of reference shore(L) $=24527, F_{1,4}=4.9, \mathrm{p}=$ 0.005). The same result was obtained using the rank position of shores around the promontory as the covariate (analysis not shown).

A total of 36 taxa were identified in the lowshore habitat (where disturbed assemblages displayed different temporal trajectories from those observed on reference shores) consistently at the 2 locations (significant $\mathrm{T} \times \mathrm{D}$ interaction in Table 1). This difference is illustrated clearly by the nMDS plot of the centroids of the disturbed and reference shores in Fig. 2b. A change in the difference between disturbed and reference shores through time could be due to a change in the magnitude of the multivariate effect, in its direction or in a combination of both. To explore this in further detail, we conducted separate multivariate analyses comparing disturbed and reference shores at each time of sampling. Differences were significant in nine out of 10 comparisons (only at T1 were the differences not

Table 2. Contribution $\left(\bar{\delta}_{i}\right)$ of individual taxa from midshore habitat to the average Bray-Curtis dissimilarity between disturbed (D) and reference (R) shores at Porto S. Stefano. Only taxa contributing $\geq 3 \%$ of percentage dissimilarity are included. Values of $\bar{\delta}_{i} / \mathrm{SD}\left(\delta_{i}\right) \geq 1$ indicate that the contribution of relevant taxon to percentage dissimilarity was consistent among pairwise comparisons of samples between reference and disturbed shores

\begin{tabular}{|lrrrrr|}
\hline Taxon & \multicolumn{2}{c}{$\begin{array}{c}\text { Average } \\
\text { abundance }\end{array}$} & $\bar{\delta}_{i}$ & $\bar{\delta}_{i} \%$ & $\bar{\delta}_{i}$ \\
& $\mathrm{R}$ & $\mathrm{D}$ & & & $\mathrm{SD}\left(\delta_{i}\right)$ \\
\hline Rivularia spp. & 8.6 & 41.7 & 23.8 & 35.6 & 1.7 \\
Chthamalus spp. & 13.0 & 36.4 & 18.3 & 27.4 & 1.5 \\
Filamentous algae & 10.0 & 2.6 & 6.8 & 10.1 & 0.9 \\
Encrusting corallines & 7.0 & 0.7 & 4.7 & 7.1 & 0.8 \\
Patella rustica & 4.9 & 0.9 & 3.4 & 5.1 & 1.0 \\
Ralfsia verrucosa & 0.5 & 2.3 & 2.3 & 3.5 & 0.3 \\
\hline
\end{tabular}

significant). These results, along with the patterns of the nMDS plot (Fig. 2b), in which the points corresponding to the disturbed and reference shores occupied distinct regions of the diagram, suggested that the $\mathrm{T} \times \mathrm{D}$ interaction was mostly due to changes in the magnitude rather than in the direction of the effect.

SIMPER identified 6 taxa that contributed to discriminate between disturbed and reference shores at different times of sampling (Table 4). Coarsely branched algae, encrusting corallines and Valonia utricularis were more common on reference shores, whilst articulated coralline algae characterized the disturbed shores. The responses of filamentous algae and Mytilus galloprovincialis were more variable, changing both in magnitude and direction during the course of the study. The contribution of filamentous algae to percentage dissimilarities was, however, consistent among pairwise comparisons of samples between disturbed and reference shores. Similar results were observed for articulate coralline and coarsely branched algae (Table 4).

The analysis of spatial pattern indicated a significant quadratic contrast for location and large interactivity between spatial and temporal sources of variation at the scale of shore (Table 3). Repeating the analysis of impact with geographic coordinates as covariables produced very similar results to those obtained from the original analysis, with a significant time $\times$ disturbed vs. reference shores interaction (Mean Square of $\mathrm{T} \times \mathrm{D}=3305.3$, Mean Square of $\mathrm{T} \times \mathrm{L} \times \mathrm{D}=1275.9$, $F_{9,9}=2.5, p=0.007$ ). The same result was obtained using the rank position of shores around the promontory as the covariate (analysis not shown).

\section{Univariate analyses}

There was large spatial and temporal variability in abundance of single taxa in the midshore habitat unrelated to disturbance (significant $\mathrm{T} \times \mathrm{R}(\mathrm{L})$ terms in

Table 3. PERMANOVA examining spatial variability in assemblages along promontory. $n t=$ no test. $p(M C)=p$-value calculated by Monte Carlo method

\begin{tabular}{|c|c|c|c|c|c|c|c|c|c|}
\hline \multirow{2}{*}{ Source of variation } & \multirow{2}{*}{ df } & \multicolumn{3}{|c|}{ — Midshore habitat — } & \multicolumn{4}{|c|}{ Lowshore habitat } & \multirow{2}{*}{$\begin{array}{l}\text { Permutable units and } \\
\text { denominator for } F\end{array}$} \\
\hline & & MS & $F$ & $\mathrm{p}$ & MS & F & $\mathrm{p}$ & $\mathrm{p}(\mathrm{MC})$ & \\
\hline Location (L) & 2 & 70323 & nt & & 85526 & 2.3 & 0.063 & 0.026 & $9 \mathrm{~S}(\mathrm{~L})$ cells \\
\hline Linear contrast (LC) & 1 & 71995 & nt & & 9117 & 0.1 & 1.0 & & $9 \mathrm{~S}(\mathrm{~L})$ cells \\
\hline Quadratic contrast (QC) & 1 & 68652 & nt & & 161936 & 4.3 & 0.016 & & $9 \mathrm{~S}(\mathrm{~L})$ cells \\
\hline Shore S(L) & 6 & 22943 & 8.2 & 0.001 & 37854 & 10.9 & 0.001 & & $90 \mathrm{~T} \times \mathrm{S}(\mathrm{L})$ cells \\
\hline Time $(\mathrm{T})$ & 9 & 9758 & 3.5 & 0.001 & 19159 & 5.5 & 0.001 & & $90 \mathrm{~T} \times \mathrm{S}(\mathrm{L})$ cells \\
\hline $\mathrm{T} \times \mathrm{L}$ & 18 & 5069 & 1.8 & 0.001 & 3331 & 1.0 & 0.6 & & $90 \mathrm{~T} \times \mathrm{S}(\mathrm{L})$ cells \\
\hline $\mathrm{T} \times \mathrm{LC}$ & 9 & 6289 & 2.2 & 0.001 & 2930 & 0.8 & 0.7 & & $90 \mathrm{~T} \times \mathrm{S}(\mathrm{L})$ cells \\
\hline $\mathrm{T} \times \mathrm{QC}$ & 9 & 3849 & 1.3 & 0.121 & 3732 & 1.1 & 0.3 & & $90 \mathrm{~T} \times \mathrm{S}(\mathrm{L})$ cells \\
\hline $\mathrm{T} \times \mathrm{S}(\mathrm{L})$ & 54 & 2804 & 2.4 & 0.001 & 3473 & 3.1 & 0.001 & & 720 raw units \\
\hline Residual & 630 & 1154 & & & 1122 & & & & \\
\hline
\end{tabular}


Table 4. Contribution $\left(\delta_{i}\right)$ of individual taxa from lowshore habitat to average Bray-Curtis dissimilarities between disturbed (D) and reference $(\mathrm{R})$ shores at each of 10 sampling times. Only taxa contributing $\geq 3 \%$ of percentage dissimilarity on at least 5 sampling occasions included. Values of $\bar{\delta}_{i} / \mathrm{SD}\left(\delta_{i}\right) \geq 1$ indicate that contribution of relevant taxon to percentage dissimilarity was consistent among pairwise comparisons of samples between reference and disturbed shores. Time designations as in Fig. 3

\begin{tabular}{|c|c|c|c|c|c|c|c|c|c|c|c|}
\hline \multirow[t]{2}{*}{ Taxon } & \multicolumn{2}{|c|}{$\begin{array}{c}\text { Average } \\
\text { abundance }\end{array}$} & \multirow[t]{2}{*}{$\bar{\delta}_{i}$} & \multirow[t]{2}{*}{$\bar{\delta}_{i} \%$} & \multirow{2}{*}{$\frac{\bar{\delta}_{i}}{\operatorname{SD}\left(\delta_{i}\right)}$} & \multirow[t]{2}{*}{ Taxon } & \multicolumn{2}{|c|}{$\begin{array}{c}\text { Average } \\
\text { abundance }\end{array}$} & \multirow[t]{2}{*}{$\bar{\delta}_{i}$} & \multirow[t]{2}{*}{$\bar{\delta}_{i} \%$} & \multirow{2}{*}{$\frac{\bar{\delta}_{i}}{\mathrm{SD}\left(\delta_{i}\right)}$} \\
\hline & $\begin{array}{l}\text { abun } \\
\mathrm{R}\end{array}$ & & & & & & & & & & \\
\hline Time 1 & & & & & & Time 6 & & & & & \\
\hline Articulated corallines & 24.7 & 30.8 & 11.1 & 17.1 & 1.3 & Articulated corallines & 28.1 & 53.6 & 13.4 & 23.8 & 1.6 \\
\hline Coarsely branched algae & 23.7 & 0.9 & 10.7 & 16.5 & 1.1 & Coarsely branched algae & 23.8 & 0.4 & 9.7 & 17.2 & 1.1 \\
\hline Filamentous algae & 27.3 & 28.3 & 9.9 & 15.3 & 1.3 & Filamentous algae & 31.7 & 59.3 & 13.6 & 24.2 & 1.6 \\
\hline Encrusting corallines & 13.5 & 6.4 & 6.6 & 10.2 & 0.9 & Encrusting corallines & 9.6 & 3.9 & 3.7 & 6.5 & 0.9 \\
\hline Mytilus galloprovincialis & 6.6 & 18.4 & 8.9 & 13.8 & 0.9 & Mytilus galloprovincialis & 6.4 & 7.9 & 4.1 & 7.2 & 0.6 \\
\hline Valonia untricularis & 6.4 & 0.0 & 2.6 & 4.0 & 0.4 & Valonia untricularis & 4.5 & 1.9 & 2.2 & 4.0 & 0.6 \\
\hline Time 2 & & & & & & Time 7 & & & & & \\
\hline Articulated corallines & 22.1 & 45.0 & 12.6 & 20.0 & 1.5 & Articulated corallines & 46.5 & 83.7 & 18.5 & 38.5 & 1.7 \\
\hline Coarsely branched algae & 24.6 & 3.9 & 9.5 & 15.1 & 1.2 & Coarsely branched algae & 21.9 & 0.0 & 10.0 & 20.9 & 1.3 \\
\hline Filamentous algae & 26.5 & 35.8 & 10.7 & 17.0 & 1.5 & Filamentous algae & 20.6 & 16.4 & 7.3 & 15.3 & 1.3 \\
\hline Encrusting corallines & 8.7 & 9.2 & 4.5 & 7.2 & 1.1 & Encrusting corallines & 6.1 & 2.6 & 2.6 & 5.3 & 0.8 \\
\hline Mytilus galloprovincialis & 8.5 & 4.8 & 3.9 & 6.3 & 0.6 & Mytilus galloprovincialis & 2.4 & 0.8 & 1.3 & 2.7 & 0.5 \\
\hline Valonia untricularis & 4.7 & 2.7 & 2.4 & 3.8 & 0.8 & Valonia untricularis & 3.1 & 1.5 & 1.9 & 4.0 & 0.5 \\
\hline Time 3 & & & & & & Time 8 & & & & & \\
\hline Articulated corallines & 48.3 & 76.1 & 17.7 & 36.8 & 1.4 & Articulated corallines & 51.8 & 90.4 & 18.5 & 41.2 & 1.5 \\
\hline Coarsely branched algae & 11.9 & 0.0 & 5.6 & 11.7 & 1.1 & Coarsely branched algae & 5.8 & 0.0 & 2.6 & 5.6 & 0.7 \\
\hline Filamentous algae & 14.4 & 19.1 & 7.5 & 15.6 & 1.3 & Filamentous algae & 24.1 & 10.1 & 8.4 & 18.6 & 1.0 \\
\hline Encrusting corallines & 9.8 & 3.4 & 5.1 & 10.5 & 0.8 & Encrusting corallines & 5.3 & 3.3 & 2.2 & 4.9 & 0.9 \\
\hline Mytilus galloprovincialis & 4.0 & 1.7 & 2.2 & 4.5 & 0.4 & Mytilus galloprovincialis & 2.5 & 0.0 & 1.0 & 2.3 & 0.3 \\
\hline Valonia untricularis & 2.6 & 0.3 & 1.3 & 2.7 & 0.4 & Valonia untricularis & 14.9 & 0.0 & 6.7 & 14.9 & 0.5 \\
\hline Time 4 & & & & & & Time 9 & & & & & \\
\hline Articulated corallines & 44.2 & 77.9 & 18.3 & 39.4 & 1.6 & Articulated corallines & 12.4 & 40.8 & 13.3 & 22.6 & 1.4 \\
\hline Coarsely branched algae & 6.9 & 0.1 & 3.3 & 7.0 & 0.6 & Coarsely branched algae & 31.7 & 2.9 & 12.7 & 21.6 & 1.3 \\
\hline Filamentous algae & 22.4 & 16.3 & 7.2 & 15.6 & 1.1 & Filamentous algae & 44.1 & 62.7 & 14.8 & 25.2 & 1.4 \\
\hline Encrusting corallines & 8.2 & 5.3 & 3.8 & 8.2 & 0.9 & Encrusting corallines & 6.7 & 0.4 & 2.6 & 4.5 & 0.7 \\
\hline Mytilus galloprovincialis & 4.9 & 4.1 & 3.3 & 7.2 & 0.7 & Mytilus galloprovincialis & - & - & - & - & - \\
\hline Valonia untricularis & 11.3 & 3.9 & 6.0 & 12.9 & 0.7 & Valonia untricularis & - & - & - & - & - \\
\hline Time 5 & & & & & & Time 10 & & & & & \\
\hline Articulated corallines & 21.2 & 38.7 & 14.4 & 27.6 & 1.3 & Articulated corallines & 25.8 & 58.8 & 16.4 & 34.8 & 1.7 \\
\hline Coarsely branched algae & 11.5 & 4.4 & 5.3 & 10.1 & 1.1 & Coarsely branched algae & 10.7 & 0.0 & 4.6 & 9.8 & 0.7 \\
\hline Filamentous algae & 33.1 & 35.8 & 9.6 & 18.4 & 1.3 & Filamentous algae & 50.5 & 44.2 & 9.8 & 20.8 & 1.3 \\
\hline Encrusting corallines & 5.3 & 4.9 & 3.5 & 6.6 & 0.8 & Encrusting corallines & 8.5 & 4.9 & 4.0 & 8.6 & 0.8 \\
\hline Mytilus galloprovincialis & 2.9 & 4.2 & 3.0 & 5.8 & 0.5 & Mytilus galloprovincialis & 2.2 & 0.0 & 0.9 & 1.8 & 0.4 \\
\hline Valonia untricularis & 6.8 & 3.9 & 4.4 & 8.5 & 0.7 & Valonia untricularis & 12.1 & 4.2 & 5.9 & 12.5 & 0.7 \\
\hline
\end{tabular}

Table 5; Fig. 3). Differences between disturbed and reference shores were significant for encrusting coralline algae, which were less abundant on disturbed than on reference shores (Fig. 3a, Table 5). Differences in temporal patterns between disturbed and reference shores that also varied between locations were evident for filamentous algae and Ralfsia verrucosa, although a significant effect (at $\alpha=5 \%$ ) was observed only in the second case $(\mathrm{T} \times \mathrm{L} \times \mathrm{D}$ interactions in Table 5, Fig. 3b,c). SNK tests within the $\mathrm{T} \times \mathrm{L} \times \mathrm{D}$ interaction for $R$. verrucosa indicated that this alga was significantly more abundant on disturbed than reference shores in 8 and 2 of the 10 possible comparisons at each location (PE and PS), respectively. A significant $\mathrm{T} \times \mathrm{D}$ interaction was observed for Rivularia spp. and for Chthamalus spp.
(Table 5; Fig. 3d,e). SNK tests indicated that Rivularia spp. and Chthamalus spp. were significantly more abundant on disturbed than reference shores in 5 and 9 comparisons, respectively. There was no evidence of differences between disturbed and reference shores for Patella rustica (Table 5, Fig. 4).

The analysis of spatial patterns revealed a significant interaction between time and the linear contrast of location only for filamentous algae (Mean Square of time $\times$ linear contrast $=677.7$, Mean Square of time $\times \mathrm{S}(\mathrm{L})=$ $\left.178.9, F_{9,54}=3.4, \mathrm{p}<0.005\right)$. Repeating the analysis of impact on filamentous algae after adjusting for differences in geographic location did not change the results of the original analysis (mean square for the $\mathrm{T} \times \mathrm{L} \times \mathrm{D}$ interaction $=0.152$, Mean Square for the $\mathrm{T} \times \mathrm{R}(\mathrm{L})$ term 
Table 5. Univariate ANOVA on data from midshore habitat. Main effects of Location and Time not tested because they were irrelevant to assessment of impact and their significance did not affect the way more relevant tests were constructed. ${ }^{*}, \mathrm{p}<0.05$; ${ }^{* *}, \mathrm{p}<0.01 ;{ }^{* * *}, \mathrm{p}<0.0001 ;$ bold $=0.05<\mathrm{p}<0.1 ; \mathrm{nt}=$ no test $;$ Ref. $=$ reference

\begin{tabular}{|c|c|c|c|c|c|c|c|c|c|c|c|c|c|}
\hline \multirow[t]{2}{*}{ Source of variation } & \multirow[t]{2}{*}{$\mathrm{df}$} & \multicolumn{2}{|c|}{$\begin{array}{l}\text { Encrusting } \\
\text { corallines }\end{array}$} & \multicolumn{2}{|c|}{$\begin{array}{l}\text { Filamentous } \\
\text { algae }\end{array}$} & \multicolumn{2}{|c|}{$\begin{array}{c}\text { Ralfisa } \\
\text { verrucosa }\end{array}$} & \multicolumn{2}{|c|}{$\begin{array}{l}\text { Rivularia } \\
\text { spp. }\end{array}$} & \multicolumn{2}{|c|}{$\begin{array}{l}\text { Chthamalus } \\
\text { spp. }\end{array}$} & \multicolumn{2}{|c|}{$\begin{array}{l}\text { Patella } \\
\text { rustica }\end{array}$} \\
\hline & & MS & $F$ & MS & $F$ & MS & $F$ & MS & $F$ & MS & $F$ & MS & $F$ \\
\hline Location (L) & 1 & 9.4 & & 989.2 & & 1118.3 & & 365.7 & & 8865.5 & & 25.351 & \\
\hline Disturbed (D) vs. Ref. (R & R) 1 & $8645.9^{\mathrm{a}}$ & $33.5^{* *}$ & 1507.0 & nt & 1888.1 & $\mathrm{nt}$ & 16037.1 & nt & 32521.7 & 5.6 & 51.362 & $\mathrm{nt}$ \\
\hline $\mathrm{L} \times \mathrm{D}$ & 1 & 122.3 & 0.3 & 3423.0 & nt & 518.8 & $\mathrm{nt}$ & 20723.2 & $\mathrm{nt}$ & 5761.6 & 1.1 & 14.404 & $\mathrm{nt}$ \\
\hline $\mathrm{R}(\mathrm{L})$ & 4 & 177.7 & 0.7 & 1073.1 & $4.6^{* *}$ & 179.6 & $12.4^{* * *}$ & 1452.0 & $9.7^{* * *}$ & 5086.1 & $20.2^{* *}$ & 22.103 & $24.5^{* * *}$ \\
\hline Time $(\mathrm{T})$ & 9 & 498.0 & & 1132.5 & & 173.2 & & 774.0 & & 787.9 & & 1.551 & \\
\hline $\mathrm{T} \times \mathrm{L}$ & 9 & 390.7 & 1.5 & 824.4 & $3.5^{* *}$ & 56.0 & $3.9^{* *}$ & 720.8 & $4.8^{* * *}$ & 230.3 & 0.9 & 1.615 & 1.8 \\
\hline $\mathrm{T} \times \mathrm{D}$ & 9 & 128.5 & 1.1 & 187.2 & 0.4 & 185.5 & 1.3 & 895.8 & $3.6^{*}$ & $700.0^{\mathrm{b}}$ & $2.8^{*}$ & 1.130 & 0.7 \\
\hline $\mathrm{T} \times \mathrm{L} \times \mathrm{D}$ & 9 & 120.8 & 0.5 & 498.5 & 2.1 & 147.4 & $10.2^{* * *}$ & 248.4 & 1.7 & 303.7 & 1.2 & 1.572 & 1.7 \\
\hline $\mathrm{T} \times \mathrm{R}(\mathrm{L})$ & 36 & 258.0 & $3.3^{* * *}$ & 235.2 & $3.2^{* *}$ & 14.5 & 0.4 & 149.2 & $1.8^{* *}$ & 251.9 & $1.5^{*}$ & 0.901 & $1.9^{* *}$ \\
\hline Residual & 560 & 77.1 & & 74.0 & & 33.6 & & 83.1 & & 171.5 & & 0.477 & \\
\hline $\begin{array}{l}\text { Cochran's } C \text {-test } \\
\text { Transformation }\end{array}$ & & $\begin{array}{l}C=0 \\
\text { Arcs }\end{array}$ & $\begin{array}{l}.053 \\
\text { ine }\end{array}$ & $\begin{array}{l}C=0 \\
\text { Arcs }\end{array}$ & $\begin{array}{l}.048 \\
\text { sine }\end{array}$ & $\begin{array}{r}C=0 . \\
\text { Nor }\end{array}$ & $\begin{array}{l}18^{* *} \\
\text { he }\end{array}$ & $\begin{array}{l}C=0 \\
\text { Arc }\end{array}$ & $\begin{array}{l}.035 \\
\text { sine }\end{array}$ & $\begin{array}{r}C=0 \\
\text { No }\end{array}$ & $\begin{array}{l}0.048 \\
\text { one }\end{array}$ & $\begin{array}{l}C=0 \\
\ln (\mathrm{x}-\end{array}$ & $\begin{array}{l}.038 \\
+1)\end{array}$ \\
\hline
\end{tabular}

$=0.072, F_{9,36}=2.1,0.05<\mathrm{p}<0.1 ;$ analysis on arcsine transformed data; test of homogeneity of slopes: Mean Square for the $\mathrm{T} \times \mathrm{L} \times \mathrm{D} \times$ latitude interaction $=0.150$, Mean Square for the $\mathrm{T} \times \mathrm{R}(\mathrm{L})$ term $=0.072, F_{9,36}=2.1$, $\mathrm{p}>0.05)$. The same result was obtained using the rank positions of shores around the promontory as the covariate (analysis not shown).

Several taxa in the lowshore habitat displayed temporal changes in abundance that differed between disturbed and reference shores consistently at the 2 locations (Table 6, Fig. 5). Significant effects of the $\mathrm{T} \times \mathrm{D}$ interaction were detected for coarsely branched and filamentous algae and for Mytilus galloprovincialis, whilst a non-significant trend $(0.05<\mathrm{p}<0.1)$ was observed for articulate coralline algae (Table 6). SNK tests within the $\mathrm{T} \times \mathrm{D}$ interaction indicated that the percent cover of coarsely branched algae was significantly lower on disturbed than reference shores in all possible comparisons. In contrast, multiple comparison tests generated inconsistent results for filamentous algae and M. galloprovincialis. Filamentous algae were significantly more abundant on disturbed shores in 2 out of

Table 6. Univariate ANOVA on data from lowshore habitat. Main effects of Location and Time not tested because they were irrelevant to assessment of impact and their significance did not affect the way more relevant tests were constructed. ${ }^{*}, \mathrm{p}<0.05$; ${ }^{* *}, \mathrm{p}<0.01 ;{ }^{* * *}, \mathrm{p}<0.0001$; bold: $0.05<\mathrm{p}<0.1 ; \mathrm{nt}=$ no test $;$ Ref. $=$ reference.

\begin{tabular}{|c|c|c|c|c|c|c|c|c|c|c|c|c|c|}
\hline \multirow[t]{2}{*}{ Source of variation } & \multirow[t]{2}{*}{$\mathrm{df}$} & \multicolumn{2}{|c|}{$\begin{array}{c}\text { Articulated } \\
\text { corallines }\end{array}$} & \multicolumn{2}{|c|}{$\begin{array}{c}\text { Coarsely } \\
\text { branched algae }\end{array}$} & \multicolumn{2}{|c|}{$\begin{array}{l}\text { Encrusting } \\
\text { corallines }\end{array}$} & \multicolumn{2}{|c|}{$\begin{array}{l}\text { Filamentous } \\
\text { algae }\end{array}$} & \multicolumn{2}{|c|}{$\begin{array}{c}\text { Valonia } \\
\text { utricularis }\end{array}$} & \multicolumn{2}{|c|}{$\begin{array}{c}\text { Mytilus } \\
\text { galloprovincialis }\end{array}$} \\
\hline & & MS & $F$ & MS & $F$ & MS & $F$ & MS & $F$ & MS & $F$ & MS & $F$ \\
\hline Location (L) & 1 & 2176 & & 17.283 & & 0.0683 & & 77.7 & & 3464.3 & & 0.346 & \\
\hline Disturbed (D) vs. Ref. (I & (R) 1 & 87886 & nt & 427.277 & $\mathrm{nt}$ & $33.237^{\mathrm{a}}$ & 1.3 & 1328.3 & nt & 3108.5 & 0.2 & 0.013 & nt \\
\hline $\mathrm{L} \times \mathrm{D}$ & 1 & 3040 & 0.2 & 8.281 & 0.3 & 0.549 & 0.0 & 4197.9 & 0.9 & 55.0 & 0.0 & 22.890 & 1.3 \\
\hline $\mathrm{R}(\mathrm{L})$ & 4 & 17366 & $19.5^{* * *}$ & 26.355 & $6.5^{* * *}$ & 26.505 & $17.6^{* * *}$ & 4560.1 & 2.4 & 12489.4 & $19.0^{* * *}$ & * 17.127 & $16.4^{* *}$ \\
\hline Time $(\mathrm{T})$ & 9 & 15150 & & 19.179 & & 2.164 & & 9210.5 & & 751.7 & & 10.396 & \\
\hline $\mathrm{T} \times \mathrm{L}$ & 9 & 1052 & 1.2 & 3.120 & 0.8 & 8.243 & $5.5^{* * *}$ & 1560.6 & 0.8 & 261.8 & 0.4 & 1.448 & 1.4 \\
\hline $\mathrm{T} \times \mathrm{D}$ & 9 & 1157 & 2.9 & 4.973 & $4.3^{*}$ & 1.696 & 1.0 & 1869.1 & $3.2^{*}$ & 209.6 & 1.2 & 2.315 & $2.4^{* \mathrm{~b}}$ \\
\hline $\mathrm{T} \times \mathrm{L} \times \mathrm{D}$ & 9 & 402 & 0.5 & 1.152 & 0.3 & 1.777 & 1.2 & 580.0 & 0.3 & 177.5 & 0.3 & 0.779 & 0.7 \\
\hline $\mathrm{T} \times \mathrm{R}(\mathrm{L})$ & 36 & 890 & $2.4^{* * *}$ & 4.041 & $4.4^{* * *}$ & 1.506 & 1.4 & 1885.8 & $8.2^{* * *}$ & 655.7 & $8.7^{* * *}$ & * 1.043 & 1.1 \\
\hline Residual & 560 & 366 & & 0.912 & & 1.107 & & 229.7 & & 75.6 & & 0.979 & \\
\hline $\begin{array}{l}\text { Cochran's } C \text {-test } \\
\text { Transformation }\end{array}$ & & \multicolumn{2}{|c|}{$\begin{array}{c}C=0.043 \\
\text { None }\end{array}$} & \multicolumn{2}{|c|}{$\begin{array}{c}C=0.045 \\
\ln (x+1)\end{array}$} & \multicolumn{2}{|c|}{$\begin{array}{c}C=0.033 \\
\ln (x+1)\end{array}$} & \multicolumn{2}{|c|}{$\begin{array}{c}C=0.038 \\
\text { None }\end{array}$} & \multicolumn{2}{|c|}{$\begin{array}{c}C=0.12^{* *} \\
\text { None }\end{array}$} & \multicolumn{2}{|c|}{$\begin{array}{c}C=0.048 \\
\ln (x+1)\end{array}$} \\
\hline
\end{tabular}


Porto Ercole
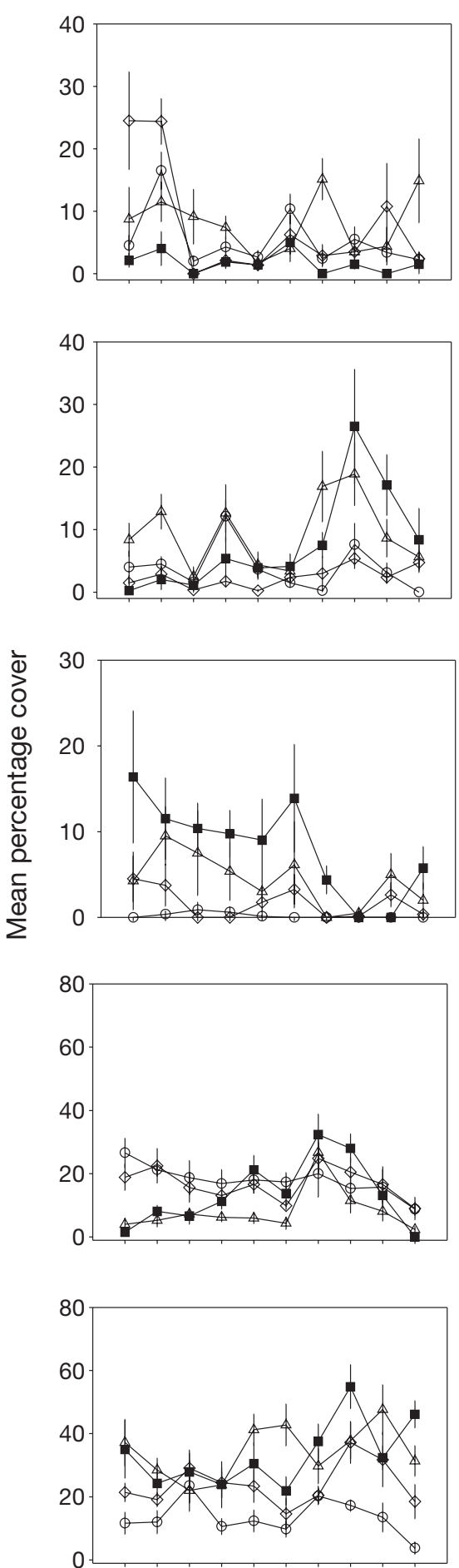

T1 T2 T3 T4 T5 T6 T7 T8 T9T10
Porto S. Stefano

a) Encrusting corallines

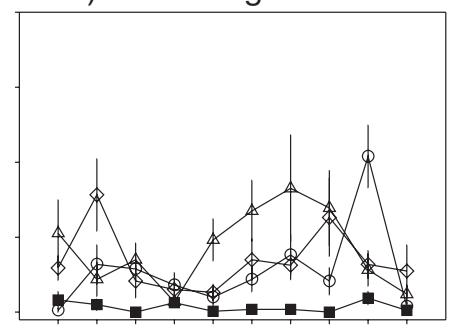

b) Filamentous algae

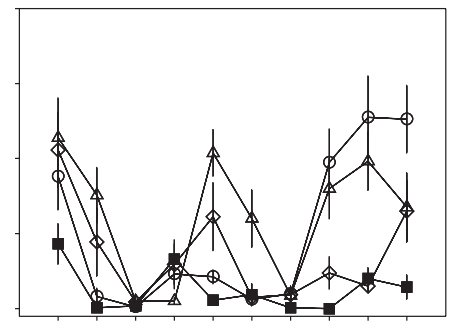

c) Ralfsia verrucosa

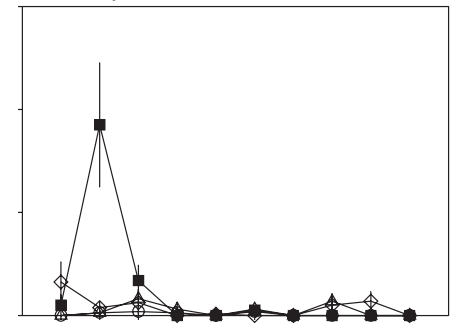

d) Rivularia spp.

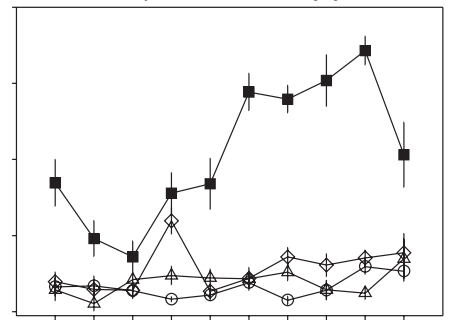

e) Chthamalus spp.

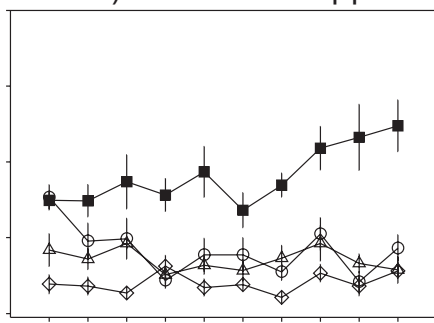

T1 T2 T3 T4 T5 T6 T7 T8 T9T10

Time

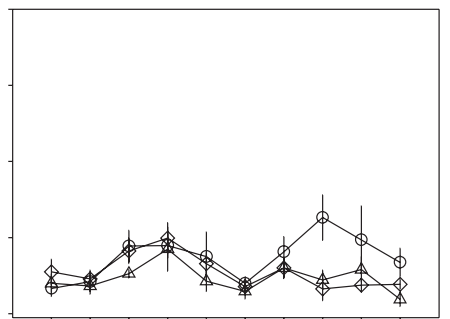

Exposed
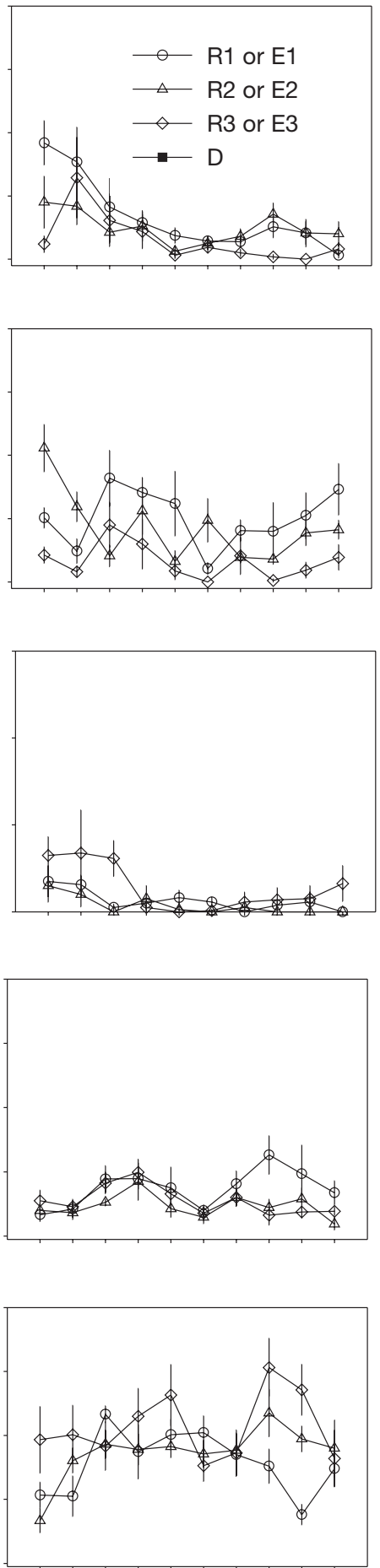

T1 T2 T3 T4 T5 T6 T7 T8 T9T10

Fig. 3. Midshore habitat. Temporal changes in mean $( \pm 1 \mathrm{SE}, \mathrm{n}=8)$ percentage cover of various taxa on disturbed $(\mathrm{D})$, reference (R) and exposed (E) shores. T1 - T4 = May, June, September, December 1998; T5 - T7 = March, June, September 1999; T8 and 9 = January, April 2000; T10 = March 2001, respectively 

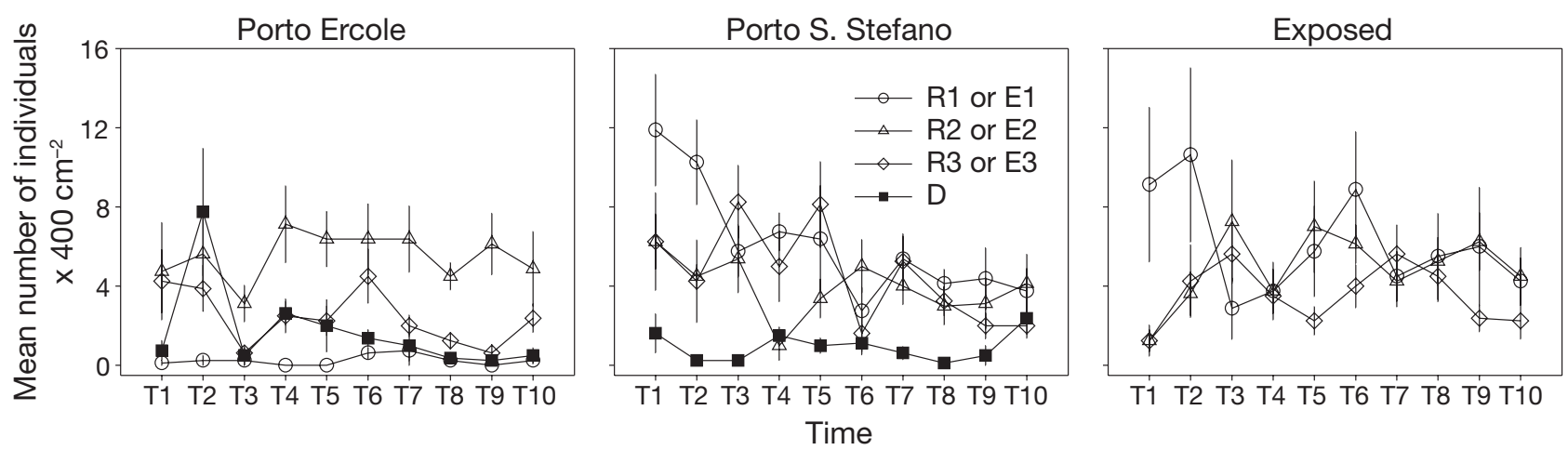

Fig. 4. Midshore habitat. Temporal changes in mean $( \pm 1 \mathrm{SE}, \mathrm{n}=8)$ density of limpets Patella rustica on disturbed $(\mathrm{D})$, reference $(\mathrm{R})$ and exposed (E) shores. See Fig. 3 for details

10 comparisons, while the opposite occurred on 1 occasion, with the remaining comparisons being not significant. Similarly, M. galloprovincialis was more abundant on disturbed than reference shores on 1 occasion, the remaining comparisons being not significant. There was no difference between disturbed and reference shores for Valonia utricularis (Fig. 5e, Table 6).

The analysis of spatial variability detected significant quadratic contrasts of location for filamentous algae (Mean Square of the quadratic contrast for location = 53424, Mean Square of $\mathrm{S}(\mathrm{L})=3443, F_{1,6}=15.5, \mathrm{p}<0.008$; analysis on untransformed data) and Mylitus galloprovincialis (Mean Square of the quadratic contrast for location = 131.1, Mean Square of $\mathrm{S}[\mathrm{L}]=13.8, F_{1,6}=9.5$, $\mathrm{p}<0.05$; analysis on untransformed data). ANCOVAs could not be done on these taxa because slopes were not homogeneous for filamentous algae (Mean Square for the $\mathrm{T} \times \mathrm{D} \times$ latitude interaction $=1870$, Mean Square for the $\mathrm{T} \times \mathrm{L} \times \mathrm{D} \times$ latitude term $=581, F_{9,9}=3.22, \mathrm{p}<0.05$ ) and the percentage cover of $M$. galloprovincialis was not linearly related with latitude $(r=-0.21, \mathrm{p}>0.6, n=8)$.

\section{DISCUSSION}

The results of this study indicated that assemblages on rocky shores next to marinas differed from those 1 to $5 \mathrm{~km}$ far from marinas, supporting the hypothesis that these structures are a source of impact to nearby organisms. Multivariate analyses on data from the midshore habitat detected differences between disturbed and reference shores at PSS, but not at PE. The same analysis conducted on the lowshore data indicated that assemblages of marinas consistently followed different temporal trajectories than those of reference shores at the 2 locations. Univariate analyses on taxa from the midshore habitat revealed a reduction in percentage cover of encrusting coralline algae on disturbed shores that was consistent over time and space. Assemblages next to marinas were dominated by barnacles
Chthamalus spp. and by the encrusting algae Ralfsia verrucosa and Rivularia spp. These taxa were consistently more abundant on disturbed shores, although the magnitude of this effect was temporally variable. Univariate analyses on data from the lowshore habitat indicated a strong reduction in cover of coarsely branched algae on disturbed shores. Although the magnitude of this effect was temporally variable, its direction was consistent across sampling dates. Differences between disturbed and reference shores were also observed for filamentous algae and for Mytilus galloprovincialis, but the magnitude and direction of these effects changed from time to time. Spatial variability around the promontory was large, as indicated by significant multivariate and univariate contrasts among locations (either as main effects or in interaction with other factors). When impacts could be examined using latitude (or the rank position of shores around the promontory) as the covariate, results did not differ from those of the original analyses. This was the case for structure of assemblages and percentage cover of filamentous algae in the midshore habitat, indicating that results were robust to the possible confounding effect of spatial processes around the promontory.

In this study we used a structured sampling design to test the hypothesis that marinas are a source of impact for assemblages on rocky shores. The logic was that of the beyond-BACI approach to the analysis of anthropogenic effects (Underwood 1991, 1992), which was applied to a post-impact case. Lack of 'before' data reduces the ability of post-impact studies to make causal inferences compared to the full 'beyond-BACI' design (Glasby 1997). Despite this limitation, postimpact studies have been used extensively to examine differences between disturbed and reference sites (Chapman et al. 1995, Roberts 1996, Lardicci et al. 1999, Guidetti et al. 2002, Terlizzi et al. 2005). Central to this approach is the use of multiple reference sites to generate an estimate of the parameter of interest for the disturbed site that would be expected in the 
Porto Ercole
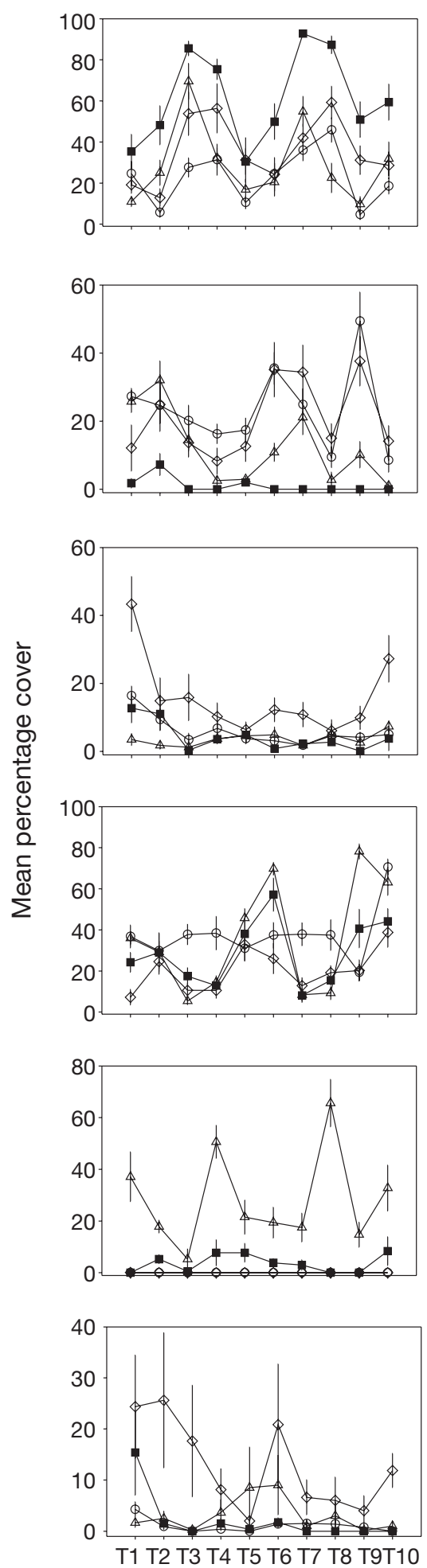

Porto S. Stefano

a) Articulated corallines

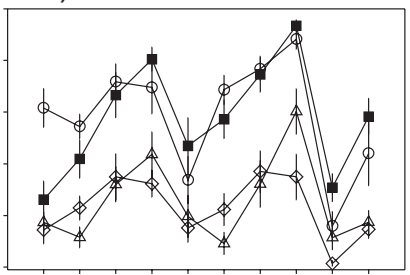

b) Coarsely branched algae

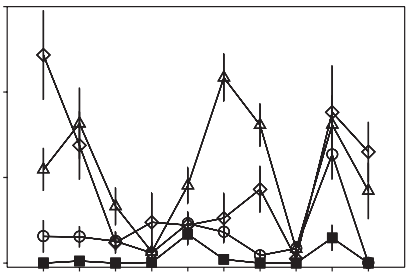

c) Encrusting corallines

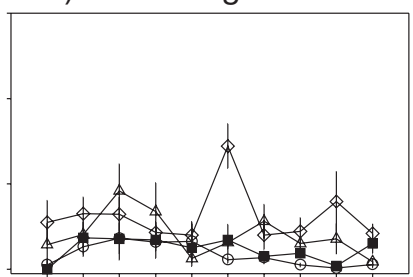

d) Filamentous algae

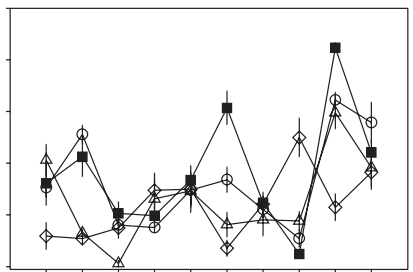

e) Valonia utricularis

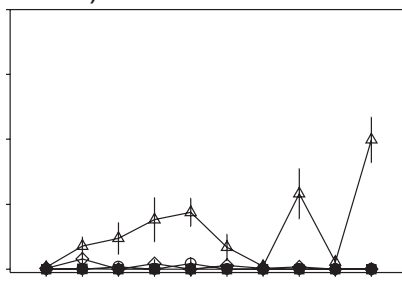

f) Mytilus galloprovincialis

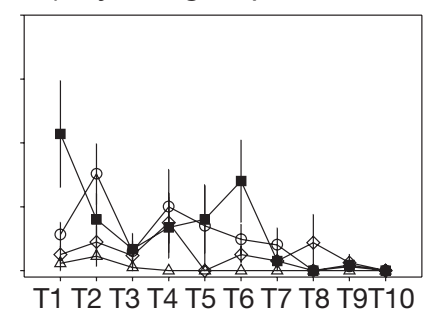

Time
Exposed
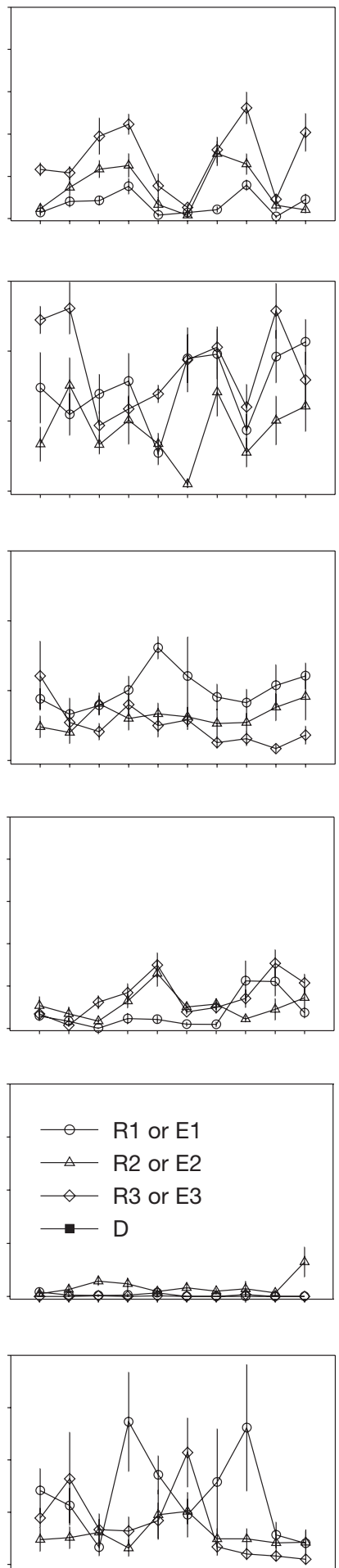

T1 T2 T3 T4 T5 T6 T7 T8 T9T10

Fig. 5. Lowshore habitat. Temporal changes in mean $( \pm 1 \mathrm{SE}, \mathrm{n}=8)$ percentage cover of various taxa on disturbed $(\mathrm{D})$, reference $(\mathrm{R})$ and exposed (E) shores. See Fig. 3 for details 
absence of impact, and to provide an accurate measure of among-site variability. The assumption is that reference and disturbed sites belong to the same population of sites in the absence of an impact.

This procedure has been criticized recently on the ground that human interventions are planned to suit specific management criteria, so that disturbed sites are not distributed randomly in the landscape (StewartOaten \& Bence 2001). This would violate the fundamental principle underpinning statistical inference that treatments and controls are allocated randomly to experimental units, impairing the ability of design-based studies to address cause-effect relationships in studies of impact. It has been argued that a model-based approach offers a better option to investigate impacts (Stewart-Oaten \& Bence 2001). In this framework, attention centers on changes at a particular site, the disturbed site, whereas reference conditions are used as covariates to reduce unexplained variability and variation among 'controls' is irrelevant to the problem of impact assessment (Stewart-Oaten \& Bence 2001).

There is no doubt that design- and model-based approaches are 2 fundamentally different philosophies in environmental impact assessment. Despite this, the 2 approaches have an important feature in common. If non-random allocation of disturbance to sites impairs the ability of structured sampling designs to establish cause-effect relationships between disturbance and impact, the model-based approach shares the same limitation because 'There will usually be many models that fit about equally well, especially when data are sparse as is common in assessment. Even if one fits better than others, this is not proof of reality (if any model can be 'real')' (Stewart-Oaten \& Bence 2001, p. 315). Thus, model-based analyses are suitable for identifying changes at a particular site, but they offer no particular advantage over design-based studies to establish cause-effect relationships between disturbance and impact.

It is instructive to consider in more detail both the limitations and the advantages of design- and modelbased approaches to the study of impact. There is no doubt that human interventions are planned according to specific criteria and that they are not distributed randomly in nature. These criteria are, however, set by humans and it should therefore be possible for the experimenter to use these same criteria to define the population of reference sites about which inferences regarding the occurrence of impacts are to be made. This can reduce the chance of confounding disturbance with other sources of variability, although it is not equivalent to a random allocation of treatments and controls to experimental units. Repetition of the choice process by which the disturbed and undisturbed conditions are allocated to spatial units cannot be guaranteed by the retrospective identification of reference sites. Hence, a difference between disturbed and reference conditions in the response variable of interest is not necessarily evidence of impact.

We argue that these limitations apply mostly to single case studies. Many kinds of human interventions do, however, offer the possibility of examining replicate events of a particular source of disturbance. Whenever the particular intervention being investigated can be repeated in space and/or in time, a genuine random selection procedure can be used to obtain a sample of effects of human disturbances. In the event that the effect differs from case to case, it is difficult to ascertain whether this is evidence of a variable impact, a spurious effect due to the inability of allocating disturbance randomly, or a combination of the two. If, in contrast, the effect is consistent among the random sample of cases examined, there is stronger evidence that an impact is occurring over and above any confounding effect that might arise due to the lack of proper randomization of disturbance.

Our results provide examples of both outcomes. Data from the midshore habitat would support the hypothesis of impact at PSS, but not at PE where variability among shores was large. Lack of a consistent response between locations weakened the conclusion that an impact was underway at PSS. We argue that a different conclusion is legitimate for the lowshore habitat, where differences in temporal trajectories between disturbed and reference shores were detected consistently at the 2 locations. It seems unlikely that the same difference between disturbed and reference conditions may have occurred systematically at both locations.

Confounding can occur systematically only if the shores next to marinas have unique features that distinguished them from any other shore in the area. Various characteristics of the coastline, including exposure to waves, contribute to the decision of whether or not a shore is adequate for the development of a marina. Although we did not measure wave action directly (e.g. Lindegarth \& Gamfeldt 2005) or other features of the coast explicitly, we used geographic position of the shores (or their rank position around the promontory) as a covariate in analyses to control for spatial gradients along the promontory, including possible effects of wave exposure. Our results indicated that spatial effects were unlikely to affect the comparison between disturbed and reference shores. Although this is not equivalent to demonstrating that an impact has occurred (is there any logical procedure that can realistically do this?), it is nevertheless evidence that the hypothesis has passed the scrutiny of a severe test in a replicated study.

The use of covariates in the analysis of environmental impacts is not free of problems. Although rarely men- 
tioned in studies of impact, ANCOVA has very restrictive assumptions that may limit the applicability of this procedure to the analysis of data from structured sampling designs. Statistical procedures that are robust to departures from assumptions are needed in order to incorporate covariates in the analysis of environmental impacts more efficiently. Selection of appropriate covariates is also a critical stage. Our analyses showed that position around the promontory, although significantly related to the abundance of some taxa, did not affect the comparison of disturbed vs. reference shores. This is illustrated by the negligible differences existing between the Mean Squares generated by ANOVAs and those obtained with ANCOVAs for any given variable. Despite these limitations, our study illustrates the possibility of including covariates in the analysis of data from structured sampling designs, an approach of potentially wide applicability in studies of impact.

Consistency of results across studies is also an important criterion to consider when deriving conclusions from studies of impact. Some of our results agree with those of other studies examining anthropogenic disturbances on assemblages on rocky shores. Terlizzi et al. (2005), for example, identified differences in temporal changes between assemblages on a rocky shore exposed to an outfall and those of reference shores, similar to those reported in the present study for the lowshore habitat. Analogous effects of outfalls were observed on single taxa in a variety of studies (Roberts et al. 1998, Archambault et al. 2001, Terlizzi et al. 2005). Although the taxa accounting for differences between disturbed and reference shores may differ among studies, a change in temporal trajectories seems to be a common response of assemblages on rocky seashores to anthropogenic disturbance.

In conclusion, the present study highlights possible ways to overcome the dichotomy between designand model-based approaches to impact assessment and to make profitable use of the advantages offered by both methodologies. First, although anthropogenic disturbances originate from a decision process and not from a random selection procedure, it is still possible to use the same criteria that underpin management decisions to select comparable reference and disturbed sites. Second, natural variability can, in principle, be reduced by incorporating covariates in the analysis of structured sampling designs. Third, even though lack of randomization prevents true replication of disturbed conditions, a random sample of differences between non-random disturbed conditions and random reference conditions can be obtained by conducting replicate studies. Finally, consistency of outcomes across different studies and different kinds of impact is a further criterion to consider when deriving conclusions from environmental analyses. We argue that more attention to these issues can significantly advance our ability to detect and interpret environmental impacts in future studies.

Acknowledgements. We sincerely thank Fabio Bulleri for commenting on an earlier version of the manuscript and Umberto Capiferri for invaluable assistance in the field. Comments and criticism from Marti Jane Anderson, Tim Glasby and an anonymous reviewer greatly improved the final version of the manuscript. This study was supported by grants from the University of Pisa, the National (COFIN) project 'Assessment of anthropogenic influences on assemblages of algae and invertebrates of rocky seas shores' and the MARBEF (Marine Biodiversity and Ecosystem Functioning) Network of Excellence, which is funded in the Community's Sixth Framework Programme (Contract no. COCE-CT2003-505446). This is contribution number MPS-07023 of MARBEF.

\section{LITERATURE CITED}

Anderson MJ (2001) A new method for non-parametric multivariate analysis of variance. Aust Ecol 26:32-46

Anderson MJ (2003) PCO: a FORTRAN computer program for principal coordinate analysis. Department of Statistics, University of Auckland

Anderson MJ (2004) DISTML v.5: a FORTRAN computer program to calculate a distance-based multivariate analysis for a linear model. Department of Statistics, University of Auckland

Anderson MJ, Robinson J (2003) Generalized discriminant analysis based on distances. Aust NZ J Stat 45:301-318

Archambault P, Banwell K, Underwood AJ (2001) Temporal variation in the structure of intertidal assemblages following the removal of sewage. Mar Ecol Prog Ser 222: $51-62$

Benedetti-Cecchi L (2001a) Beyond BACI: optimization of environmental sampling designs through monitoring and simulation. Ecol Appl 11:783-799

Benedetti-Cecchi L (2001b) Variability in abundance of algae and invertebrates at different spatial scales on rocky sea shores. Mar Ecol Prog Ser 215:79-92

Benedetti-Cecchi L, Maggi E, Bertocci I, Vaselli S, Micheli F, Osio GC, Cinelli F (2003) Variation in rocky shore assemblages in the north-western Mediterranean: contrasts between islands and the mainland. J Exp Mar Biol Ecol 293: 193-215

Bernstein BB, Zalinski J (1983) An optimum sampling design and power test for environmental biologists. J Environ Manag 16:335-343

Bishop MJ, Underwood AJ, Archambault P (2002) Sewage and environmental impacts on rocky shores: necessity of identifying relevant spatial scales. Mar Ecol Prog Ser 236: 121-128

Bulleri F, Chapman MG (2004) Intertidal assemblages on artificial and natural habitats in marinas on the north-west coast of Italy. Mar Biol 145:381-391

Cavaleri L (2005) The wind and wave atlas of the Mediterranean Sea: the calibration phase. Adv Geosci 2: $255-257$

Chapman MG, Underwood AJ, Skilleter GA (1995) Variability at different spatial scales between a subtidal assem- 
blage exposed to the discharge of sewage and two control assemblages. J Exp Mar Biol Ecol 189:103-122

Clarke KR (1993) Non-parametric multivariate analyses of changes in community structure. Aust Ecol 18:117-143

Clarke KR, Gorley RN (2001) PRIMER v5: User manual/tutorial. Primer-e, Plymouth

Connell SD, Glasby TM (1999) Do urban structures influence local abundance and diversity of subtidal epibiota? Mar Environ Res: 47:373-387

Dethier MN, Graham ES, Cohen S, Tear LM (1993) Visual versus random-point percent cover estimations: 'obiective' is not always better. Mar Ecol Prog Ser 96:93-100

Dutilleul P (1993) Spatial heterogeneity and the design of ecological field experiments. Ecology 74:1646-1658

Eberhardt LL, Thomas JM (1991) Designing environmental field studies. Ecol Monogr 61:53-73

Glasby TM (1997) Analysing data from post-impact studies using asymmetrical analysis of variance: a case study of epibiota on marinas. Aust Ecol 22:448-459

Glasby TM, Underwood AJ (1998) Determining positions for control locations in environmental studies of estuarine marinas. Mar Ecol Prog Ser 171:1-14

Green RH (1979) Sampling design and statistical methods for environmental biologists. Wiley Interscience, Chichester

Guidetti P, Fanelli G, Fraschetti S, Terlizzi A, Boero F (2002) Coastal fish indicate human-induced changes in the Mediterranean littoral. Mar Environ Res 53:77-94

Guidetti P, Terlizzi A, Fraschetti S, Boero F (2003) Changes in Mediterranean rocky-reef fish assemblages exposed to sewage pollution. Mar Ecol Prog Ser 253:269-278

Hewitt JE, Thrush SF, Cummings VJ (2001) Assessing environmental impacts: effects of spatial and temporal variability at likely impact scales. Ecol Appl 11:1502-1516

Huitema BE (1980) The analysis of covariance and alternatives. Wiley Interscience, New York

Lardicci C, Rossi F, Maltagliati F (1999) Detection of thermal pollution: variability of benthic communities at two spatial scales in an area influenced by a coastal power station. Mar Pollut Bull 38:296-303

Legendre P, Legendre L (1998) Numerical ecology, 2nd English edn. Elsevier Science, Amsterdam

Lindegarth M, Gamfeldt L (2005) Comparing categorical and continuous ecological analyses: effects of 'wave exposure' on rocky shores. Ecology 86:1346-1357

Littler MM, Littler DS (1980) The evolution of thallus form and survival strategies in benthic marine macroalgae: field and

Editorial responsibility: Roger Hughes (Contributing Editor), Bangor, UK laboratory tests of a functional form model. Am Nat 116: $25-44$

McArdle BH, Anderson MJ (2001) Fitting multivariate models to community data: a comment on distance-based redundancy analysis. Ecology 82:290-297

Quinn GP, Keough MJ (2002) Experimental design and data analysis for biologists. Cambridge University Press, Cambridge

R Development Core Team (2003) R: a language and environment for statistical computing. R Foundation for Statistical Computing, Vienna. (also available at: www.R-project.org)

Roberts DE (1996) Effects of the North Head deep-water sewage outfall on nearshore coastal reef macrobenthic assemblages. Mar Pollut Bull 33:303-308

Roberts DE, Smith A, Ajani P, Davis AR (1998) Rapid changes in encrusting marine assemblages exposed to anthropogenic point-source pollution: a 'Beyond BACI' approach. Mar Ecol Prog Ser 163:213-224

Schmitt RJ, Osenberg CW (1996) Detecting ecological impacts: concepts and applications in coastal habitats. Academic Press, San Diego, CA

Steneck RS, Watling L (1982) Feeding capabilities and limitation of herbivorous molluscs: a functional group approach. Mar Biol 68:299-319

Stewart-Oaten A, Bence JR (2001) Temporal and spatial variation in environmental impact assessment. Ecol Monogr 71: 305-339

Terlizzi A, Benedetti-Cecchi L, Bevilacqua S, Fraschetti S, Guidetti P, Anderson MJ (2005) Multivariate and univariate asymmetrical analyses in environmental impact assessment: a case study of Mediterranean subtidal sessile assemblages. Mar Ecol Prog Ser 289:27-42

Underwood AJ (1991) Beyond BACI: experimental designs for detecting human environmental impacts on temporal variations in natural populations. Aust J Mar Freshw Res 42: 569-587

Underwood AJ (1992) Beyond BACI: the detection of environmental impacts on populations in the real, but variable, world. J Exp Mar Biol Ecol 161:145-178

Underwood AJ (1997) Experiments in ecology. Their logical design and interpretation using analysis of variance. Cambridge University Press, Cambridge

Underwood AJ, Chapman MG (2003) Power, precaution, Type II error and sampling design in assessment of environmental impacts. J Exp Mar Biol Ecol 296:49-70

Submitted: February 7, 2006; Accepted: July 31, 2006

Proofs received from author(s): March 5, 2007 